\title{
Influence of Parent Involvement to Children's Learning Intrest During Corona Virus Pandemic
}

\author{
Manan $^{1}$, La Jeti ${ }^{2 凶}{ }^{\bowtie}$ Adnan $^{3}$ \\ Pendidikan dan Sastra Indonesia, Universitas Muhammadiyah Buton(1) \\ Pendidikan Guru Pendidikan Anak Usia Dini, Universitas Muhammadiyah Buton(2,3) \\ DOI: $\underline{10.31004 / \text { obsesi.v5i2.1145 }}$
}

\begin{abstract}
This research aimed to obtain information about influence of parental involvement on children's learning interests at home during the corona virus pandemic. This research used a quantitative approach to the type of ex-post facto research. The population in this research consisted of 90 parents and students. This research was conducted in Buton Regency. The data collection method used a questionnaire and used simple regression analysis. Based on the hypothesis tested, it found a positive and significant influence on children's interest in learning at home during the corona virus pandemic with a regression coefficient of 72,749 and a significant value (sig) of $0,000<0.05$. Parents' involvement in the parenting in program was to provide support, respect the work of children, guide, supervise and discipline. Teaching children at home, Providing motivation, Building good communication with children and school environment to find out the child's development, Building cooperation with schools and the community.
\end{abstract}

Keywords: parents; children; learning

\begin{abstract}
Abstrak
Penelitian ini bertujuan untuk memperoleh informasi tentang pengaruh keterlibatan orang tua terhadap minat belajar anak di rumah selama pandemi virus corona. Penelitian ini menggunakan pendekatan kuantitatif dengan jenis penelitian ex-post facto. Populasi dalam penelitian ini terdiri dari 90 orang tua dan siswa. Penelitian ini dilakukan di Kabupaten Buton. Metode pengumpulan data menggunakan kuesioner dan menggunakan analisis regresi sederhana. Berdasarkan hipotesis yang diuji, ditemukan pengaruh yang positif dan signifikan terhadap minat belajar anak di rumah selama pandemi virus corona dengan koefisien regresi 72.749 dan nilai signifikan (sig) $0,000<0,05$. Adapun keterlibatan orang tua meliputi : Keterlibatan orang tua dalam program parenting adalah memberikan dukungan, menghargai pekerjaan anak, membimbing, mengawasi dan disiplin. Mengajar anak dirumah, Memberi motivasi, Membangun komunikasi yang baik dengan anak dan lingkungan sekolah untuk mengetahui perkembangan anak, Membangun kerjasama dengan sekolah dan masyarakat.
\end{abstract}

Kata Kunci: orang tua; anak; pembelajaran

Copyright (c) 2021 Manan, La Jeti, Adnan

$\triangle$ Corresponding author:

Email Address : lajeti469@gmail.com (Buton, Indonesia

Received 12 February 2021, Accepted 18 February 2021, Published 18 February 2021 


\section{INTRODUCTION}

The smart and character generation must get a good education early through formal, informal and non-formal education. The awareness of educators and parents is the main key to optimal growth and development of children. That awareness is engraved in every educator that children are born with all their potential. Early childhood is a potential age that has the ability to absorb information mainly through language in environment. Montessori Lillard (2016) said that early childhood has sensitivity to language or is called sensitive of language. That is, children will be easy to master both mother tongue and second language. Through guidance, direction and good support will become a fundamental factor for children's language development.

On the other hand, early childhood has a period that is very sensitive to various information in their environment. At this age, children have an intellectual capacity of $80 \%$, which means that children have a strong grasp of the information obtained. In her theory, According to Montessori (1959) that children at an early age have a quick absorption or better known as the Absorbent Mind. Information that enters through the child's senses is quickly absorbed into the brain. The absorption capacity of a child's brain can be likened to a sponge that quickly absorbs water. therefore, educators should not be mistaken in providing concepts to children.

Along with the times of science and technology change the perspective of informal education as a concept of family education and switch to non-formal education and fully formal. This is certainly based on several factors both, social economic status of society, education level, and career, so that children's education is more focused on formal education. Amidst the course of education in the 21st century, the world is precisely no exception, Indonesia is hit by a deadly corona virus pandemic, this situation requires all activities to cease including normal learning and online activities. But the interesting is that in early childhood education, access to online learning is limited, so parents are the main key to children's learning, so that the children's learning environment does not have to decrease amidst this pandemic, even though they are not learning normally. Mathews et al. (2017) concluded that learning child at home had the effect to the child learning motivation and character building.

The pandemic situation, has restored awareness of the importance of family education, so far it has rarely been done by some families. Family education or modern called Parent involment is the involvement of parents in development of children both in terms of parenting, volunteers, communication, learning at home and making decisions. This research giving the strategy to parents in learning during corona virus. The research supported by the reaseach conducted by Azlan et al. (2020) concluded that Malaysians have an acceptable level of knowledge on COVID-19 and are generally positive in their outlook on overcoming the pandemic. Even so, consistent messaging from the government and/ or health authorities are key to aid public knowledge and understanding of COVID-19. Additionally, some categories of the population may benefit from specific health education programs to raise COVID-19 knowledge and improve practices.

According to Kidman \& Thurman (2014) in the concept of parenting are directly involved in fulfilling: Physical needs, parents must meet basic needs in the family such as clothing, food and shelter. Emotional needs, in addition to physical needs emotional needs become important for parents to fulfill by loving children, understanding and respecting children. Intellectual needs, parents also have to meet the intellectual needs of children by educating children, teaching subjects learned at school. Social needs, social needs are very important for children, thus parents need to provide active space for children to make friends and communicate with their environment. Protection need, the need for security, children need security from threats, both threats from physical, verbal and sexual violence.

The researc indicated that a continued focus on supporting community understanding of the rationale for these strategies, as well as instilling community confidence in their ability to adopt or sustain the recommendations is needed (Seale et al., 2020). Spiritual need, the need 
for faith and piety become the basis for the growth and development of a good child's soul. Parents not only meet the physical needs of children but the child's faith to get closer to the creator becomes fundamental. Spiritual education. character values through modelling and habituation in the family is the key to success. This research supported by the research Gardner et al. (2018) concluded that the parenting behavior influenced the child behavior. The family is the first environment for children to get education, care, motivation and guidance from birth to adulthood. The family is divided into two parts namely a large family consisting of father and mother, grandmother, grandfather, aunt and uncle, while the nuclear family consists of father and mother with their children. The family in the sense that both parents have a very big responsibility for the growth and development of their children, both physically and spiritually. Based on researched Mahoney \& Wiggers (2007) concluded that the active role of parents, as mediators, motivators have a good impact on children's learning at home, social emotional and children's learning develops well. Escalante-Barrios et al. (2020) concluded that interaction The parent-child is a cornerstone of early childhood development and oneway early childhood programs can have a positive influence on early development.

Currently, all countries in the world are no exception, Indonesia is being hit by nonnatural or health-related disasters called covid 19 (Corona virus deseas nineteen). This virus was first discovered in Wuhan China and spread throughout the world, resulting in quite a lot of deaths. The impact of this virus not only threatens public health but also the people's economy and education. The research conducted by Kadir et al. (2019) showed that mortality, injuries, illnesses, environmental exposures, limitations in access to health care and education, and the experience of violence, including torture and sexual violence. Studies also described conflict-related social changes affecting child health.

In the midst of the corona virus pandemic, all educational institutions are not lost. Early childhood education is closed to prevent the spread of the corona virus. We realize that this virus has a direct impact on the teaching and learning process, especially in kindergarten who cannot online-based learning. So family education is very important when learning situations is not normal. Parents must not only be educators as parents but act as teachers like formal education. Besed on researched by Fasina (2011) suggests the role of parents in early childhood education in areas where learning resources are very limited. The results of this researched show that parental involvement is important and fundamental in children's education to help children from learning limitations, improve children's social relationships and teach about self-esteem and interest in learning for children.

The research conducted by Dankiw et al. (2020) concluded that the positive impacts of nature play were encouraging in terms of physical activity and cognitive development, nature play stakeholders should focus on producing a universal definition for nature play, the development of standardised outcome measures and the conduct of robust research designs. Implications of these findings suggest the need for the development of standardised guidelines to inform practice and policy in the design of children's play spaces in different contexts.

Espinoza et al. (2020) concluded that Unrestricted mobility between the two risk communities increases the number of secondary cases in the low-risk community but reduces the overall epidemic size. By contrast, the imposition of a cordon sanitaire around the highrisk community reduces the number of secondary infections in the low-risk community but increases the overall epidemic size. The situation of this pandemic is that parental involvement is very important to keep the learning process at home. During this time parents are not much involved in children's learning because of busyness and careers, but at this time the family becomes the main education. Parental involvement would not be successful if communication between the teacher and parents is not well developed, therefore the involvement of the teacher and parents must be built properly in the midst of a pandemic. 


\section{METHOD}

This study used a quantitative approach to the type of ex-post facto research, because it seeks relationships that affect each other and is not manipulated or treated to variables and data obtained in this research. The population in this research are parents who have an early childhood education group B Kindergarten in Buton regency, with a total of 90 parents and childres with criteria included; who has low access internet and low standar economy. Sampling in this study using random sampling techniques. This sample technique is a random sampling technique from all populations with certain criteria to be used as samples.

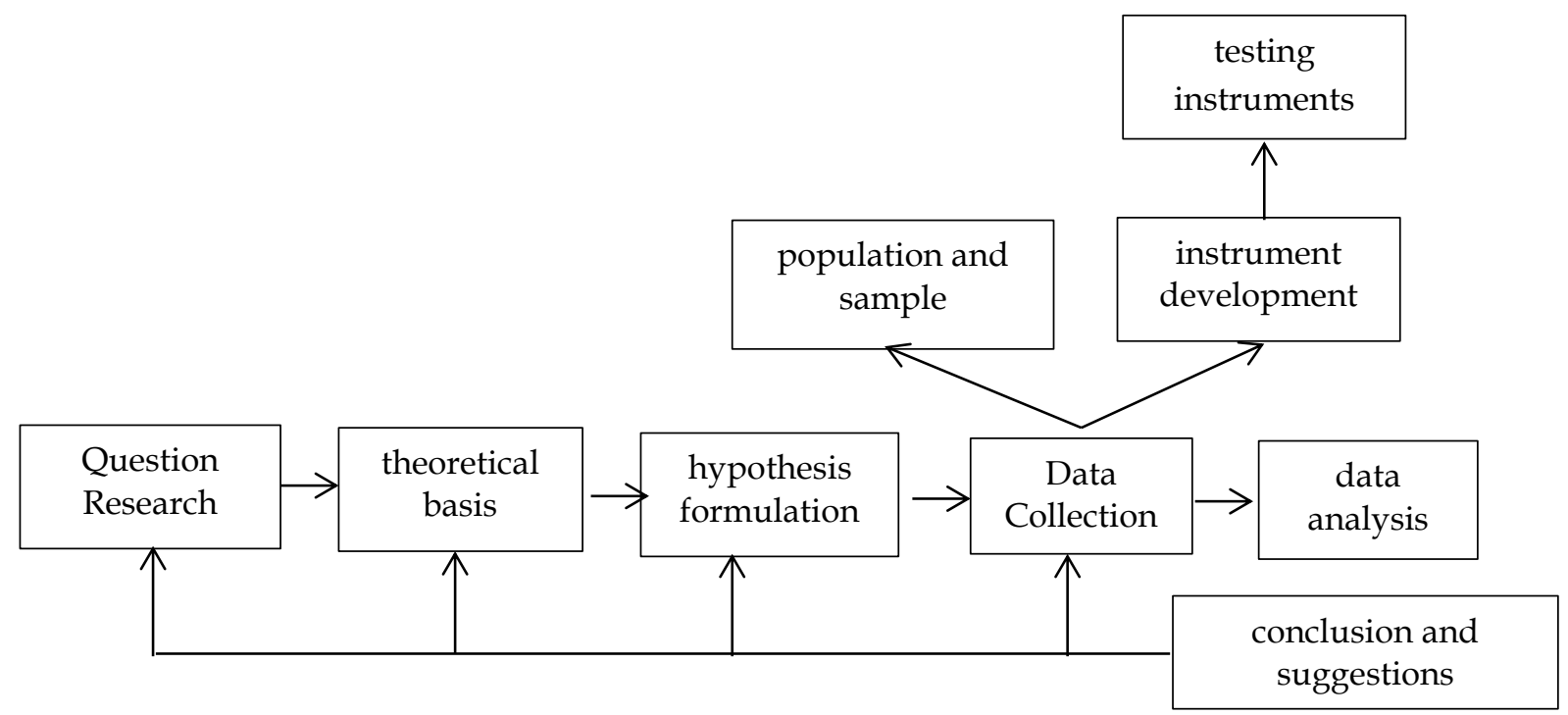

Picture 1. Chart of research stage

The data in this study were collected by distributing questionnaires to the respondents namely parents of the City of Baubau. Questionnaire to parents and childrens with the number of statement items 40 numbers with alternative answer choices using the Likert scale. The data collection instrument used in this research was a questionnaire. Researchers used a questionnaire to obtain data on parent involvement and children learning interest. The questionnaire contains questions or statements related to variables to be studied and answered or responded by respondents with alternative answer choices or answer options.

Hypothesis testing in this research used simple regresis analysis. Regression analysis for processing this data uses SPSS 16.0For Windows. The purpose of this analysis is to find the effect of independent variables on the dependent variable. The independent variable in this research is Parent Involvement and the dependent variable is Children Learning Intrest during the corona virus pandemic.

\section{RESULT AND DISCUSSION}

The hypothesis of this research was there is a positive influence of parental involvement on the learning interest of kindergarten children during the corona virus pandemic. The results of hypothesis testing could be seen in the following regression coefficient table 1.

The coefficient table data above could be explained that the regression equation model is $Y=72,749+0.384 X$. This model means that without parents involvement, learning interest is 72,749 . The regression coefficient of parental involvement $(\mathrm{x})$ of was 0.384 . This means that any change in parental involvement has decreased interest in learning as 0.384 or or $38.4 \%$. T value of 5.383 is greater than 0.202 or a significance value of 0.00 is smaller than alpha 0.05 . This means that parental involvement has a positive and significant effect on children's interest in learning during the corona virus pandemic. 
Table 1. Coefficients regression

\begin{tabular}{|c|c|c|c|c|c|}
\hline \multirow[b]{2}{*}{ Model } & \multicolumn{2}{|c|}{$\begin{array}{l}\text { Unstandardized } \\
\text { Coefficients }\end{array}$} & \multirow{2}{*}{\begin{tabular}{|c|}
$\begin{array}{c}\text { Standardized } \\
\text { Coefficients }\end{array}$ \\
Beta \\
\end{tabular}} & \multirow[b]{2}{*}{$\mathrm{t}$} & \multirow[b]{2}{*}{ Sig. } \\
\hline & B & Std. Error & & & \\
\hline (Constant) & 72.749 & 13.515 & & 5.383 & .000 \\
\hline$x$ & .384 & .127 & .436 & 3.024 & .004 \\
\hline
\end{tabular}

The research hypothesis stated that Parental involvement has positive influences children's interest in learning. A constant value of 72.749, this means that Children's Learning Interest would be 72.749 if Parent Involvement is equal to zero. It could be explained that Children's Learning Interest will decrease if there is no Parental Involvement. The Parent Involvement Variable has a positive influence on Children Learning Interest during the corana virus pandemic with a regression coefficient of 0.384 indicating that if Parent Involvement increases by 0.384 percent assuming the other independent variables were constant. Significant value (sig) of 0,000 , this value is much lower compared to 0.05 , the influence of Parental Involvement on Children's Learning Interest is significant. Research conducted (Yulianingsih et al., 2020) concluded that parents have a role as child teachers, child needs providers, spiritual teachers, supervisors, motivators, and child facilities providers. Children's learning assistance can be seen from the way parents help children's task difficulties, explain material that children do not understand, and respond well to all online learning from school.

The results of this research are consistent with the results of research conducted by (Irma et al., 2019) which stated that Parent Involvement has a significant influence to children learning motivation during stay home. The results support the hypothesis that the Parent Involvement variable partially has positive effect on Children's Interest in Learning home during the corona virus pandemic. This is indicated by the regression coefficient value of 0.384 which states that every increase of Parent Involvement of 1 unit would increase the children learning intrest was 0,384. Probability was less then 5\% namely $0,000<0,05$ indicated that parent involvement has positive and significant on children learning interest at home during the coronavirus pandemic.

In this research, Parent Involvement has the role of parenting, communication, volunteer, lerning at home, making decisions, and collaboration with societies programs.. This means that parents in the parenting program are providing support, respecting children's work, guiding, supervising and disciplining. In communication parents are involved in discussions with the teacher and the child's parents to discuss the development of the child at school and at home. While research (Mufaziah \& Fauziah, 2020) concluded that need for the attention of teachers to give assignments through collaboration with parents. Because integration between parents, teachers and students is the main key to the learning process

Research Conducted by Nirmala \& Annuar (2020) showed that around $84.3 \%$ of teachers implemented home visit strategy as learning during a pandemic. As for the stages, namely: 1) the preparation stage; 2) implementation stage; 3) the follow-up activity stage; and 4) the monitoring and evaluation stage. This home visit strategy is a solution for ECE teachers with all their limitations to continue provide the best service for early childhood in the 3T area.

Parents are involved in helping the difficulties of children, Following training held by schools, through teachers visiting students or parents of sick students with health protocol rules, conveying the progress of their development, participation in school activities. Fu et al.(2017) concluded that low parent involvement at home had the influenced to child learning motivation, behavior. Research Objectives. Teaching children at home during the corona virus pandemic, Providing motivation, Building good communication with children and the school environment to find out children's development, Building cooperation with schools and the 
community. The results of research conducted by (Erdener \& Knoeppel, 2018) concluded that parental involvement has an influence on children's learning outcomes. There are six types of parental involvement between parents and school are parenting, communicating, volunteering, learning at home, decision-making, and collaborating with the community. The research conducted Malti et al. (2012) concluded that accustomed the child to share, help, symphaty, cooperation could shape the behavior and child academic.

Parental involvement during the corona virus pandemic could be increase children's interest learning at home including, quriosity, having motivation to continue learning through play activities, Performing non-coercive, Making work independently, Repeating learning, Doing physical motor activities at home, Loving learning, Persevering learning that kindergarten has learned. With the involvement of good parents, every child is able to solve the problem properly. Poulain et al. (2020) concluded that parent involvent has influenced to childs motivation, grade school and motor skill development.

In addition, children could be motivated and have high self-confidence. Parent involvement marked by encouragement processes carried out at home that could support any shortcomings of the learning process that has been obtained at school would have a positive effect on children's learning interests during the corana virus pandemic. (Bhopal et al., 2019) concluded that child learning was influenced by the social condition. The Corona virus has the effect to social condition and economic parents. This situation parents and teacher could collaborated to conducted learning process in pandemic.

The results of research conducted by Fasina (2011) showed that parental involvement in providing love, supervision, discipline, tutoring while at home could have a positif and significant influence on children's learning motivation at home and in kindergarten environments showing interest in learning, empathy and having high self-efficacy. This showed that the involvement of parents has a major influence on children's interest in learning during the corona virus pandemic.

while the research of conducted by Fujiwara et al. (2011) showed that Parental involvement has positive and significant influences on early childhood education. The involve of parent were Parental affection, guidance, warm communication becomes more effective in early childhood education, children are more controlled, have a sense of empathy, high motivation to learn and lack the level of depression of children in the learning process at home. To create integrated learning and provide support to family students has an important role. Parents build cooperation with the school and are jointly responsible for the success of students. This research supported by the results of research conducted by Đurišić \& Bunijevac (2017) concluded that the involvement of parents could increase parental awareness to support school learning programs and have a positive impact on learning. In this study parental participation and involvement included six aspects namely : Communicating, Volunteering, Learning at home, Decision-making and Collaborating with the community. The results of research conducted by Yulianti et al. (2019) concluded that the involvement of parents had a positive and significant influence on student learning outcomes. The results of this reseach also explain that parents and teachers are directly involved, mutually support each other, conduct joint training and observe the development of students.

Research of Juwita et al. (2019) concluded that in essence teachers and parents were an inseparable component. The results of this research showed a positiveand significant impact on children learning motivation. Parents, teachers and school programs, among others, facilitating children's learning, guiding, increasing parents' motivation, increasing children's learning motivation and building harmonious relationships. The family is the first and foremost place for children from birth, it is in the family environment that children get their first education, so it is right in the midst of a corona virus outbreak that parents get involved again to educate their children at home. While the research of conducted by Juwariyah et al. (2019) The results of this researche indicated that parental involvement could have a positive impact on children's development, through this research it can be seen that parents who 
provide space for children, children can express their interests and limitations certain of parents. Involvement between parents and active teachers can provide benefits for children's development, also made children more friendly when in the school environment. According to Bronfenbrenner (1979) In the concept of microsystems the relationship between parents and school is built. Collaboration between parents and school is the main key to successful learning with health protocol rules. The research conducted by (Kim et al., 2020) concluded that by implementation health protocol could decrease the impact of corana virus, including; using mask, washing hand, and social distancing

The involvement between parents and teachers is very important to teach and educate the children at home during the corona virus pandemic. During an early childhood corona pandemic is dissolved and online learning cannot be carried out directly. Therefore, parents have an important role to be directly involved in children's education during the corona pandemic at home. The researh conducted Hart et al. (2016) concluded that parent involvement learning at home has the effect to child learning achievement, parenta growing literature concerning the role of the home math environment in children's math development. Parents who reported doing more general math activities in the home reported having children with higher math skills.

\section{CONCLUSION}

Based on results of this researche it could be concluded that involvement of parents on children's learning interests has a positive and significant influence on children learning intrest at home during corona virus pandemic. Parental involvement is caring for children with affection, giving punishment guiding, advising, disciplining, warm communication within the family, studying together at home, helping to complete children's learning tasks, engaging in school and community activities, making decision arrange the rules together with school, parent involve with school with health protocol rules, so that parental involvement is very important and as strategy in childern learning during covid 19.

\section{ACKNOWLEDGMENT}

Alhamdulillahi rabil 'alamin, the researcher expresses the highest gratitude to Allah Subhanahu wa ta'alaa, for blessing, love, apportunity, health and mercy to complete this paper. Appreciation and thanks to Dr. Wa Ode Alzarliani, S.P.,M.M. as the Rector of Muhammadiyah Buton University who have given the support and motivation. Appreciation and thanks to informan who have given the information for completing this research. Appreciation and thanks to Obsesi Journal as Publisher this paper.

\section{REFERENCES}

Azlan, A. A., Hamzah, M. R., Sern, T. J., Ayub, S. H., \& Mohamad, E. (2020). Public knowledge, attitudes and practices towards COVID-19: A cross-sectional study in Malaysia. Plos One, 15(5), e0233668. https:// doi.org/10.1371/journal.pone.0233668.

Bhopal, S., Roy, R., Verma, D., Kumar, D., Avan, B., Khan, B., Gram, L., Sharma, K., AmengaEtego, S., \& Panchal, S. N. (2019). Impact of adversity on early childhood growth \& development in rural India: Findings from the early life stress sub-study of the SPRING cluster randomised controlled trial (SPRING-ELS). PloS One, 14(1), e0209122. https:// doi.org/10.1371/journal.pone.0209122.

Bronfenbrenner, U. (1979). The ecology of human development. Harvard university press.

Dankiw, K. A., Tsiros, M. D., Baldock, K. L., \& Kumar, S. (2020). The impacts of unstructured nature play on health in early childhood development: A systematic review. PloS One, 15(2), e0229006. https://doi.org/10.1371/journal.pone.0229006.

Đurišić, M., \& Bunijevac, M. (2017). Parental involvement as a important factor for successful education. Center for Educational Policy Studies Journal, 7(3), 137-153. 
DOI: $10.31004 /$ obsesi.v4i2.1073

Erdener, M. A., \& Knoeppel, R. C. (2018). Parents' Perceptions of Their Involvement in Schooling. International Journal of Research in Education and Science, 4(1), 1-13. https://doi.org/10.21890/ijres.369197

Escalante-Barrios, E. L., Suarez-Enciso, S. M., Raikes, H., Davis, D., Garcia, A., Gonen, M., Veziroglu-Celik, M., \& Hazar, R. G. (2020). Child-parent interactions in American and Turkish families: Examining measurement invariance analysis of child-parent relationship scale. Plos One, 15(4), e0230831.

Espinoza, B., Castillo-Chavez, C., \& Perrings, C. (2020). Mobility restrictions for the control of epidemics: When do they work? Plos One, 15(7), e0235731.

Fasina, F. (2011). The Role of Parents in Early Childhood Education: A case Study of Ikeja, Lagos State. Global Journal of Human Social Science, 11(2), 43-51.

Fu, M., Xue, Y., Zhou, W., \& Yuan, T.-F. (2017). Parental absence predicts suicide ideation through emotional disorders. PLoS One, 12(12), e0188823. https://doi.org/10.1371/journal.pone.0188823.

Fujiwara, T., Kato, N., \& Sanders, M. R. (2011). Effectiveness of Group Positive Parenting Program (Triple P) in changing child behavior, parenting style, and parental adjustment: An intervention study in Japan. Journal of Child and Family Studies, 20(6), 804-813. https:// doi.org/10.1007/s10826-011-9448-1.

Gardner, F., Melendez-Torres, G., Knerr, W., \& Overbeek, G. (2018). Parenting behaviors that shape child compliance: A multilevel meta-analysis.

Hart, S. A., Ganley, C. M., \& Purpura, D. J. (2016). Understanding the home math environment and its role in predicting parent report of children's math skills. PloS One, 11(12), e0168227. https:// doi.org/10.1371/journal.pone.0168227.

Irma, C. N., Nisa, K., \& Sururiyah, S. K. (2019). Keterlibatan orang tua dalam pendidikan anak usia dini di TK Masyithoh 1 Purworejo. Jurnal Obsesi: Jurnal Pendidikan Anak Usia Dini, 3(1), 214-224. https://doi.org/10.31004/obsesi.v3i1.152.

Juwariyah, S., Slamet, A., \& Kustiono, K. (2019). Analysis of Parenting and Involvement of Parents in Early Childhood. Journal of Primary Education, 8(3), 364-370.

Juwita, T., Suminar, T., \& Handayani, S. S. D. (2019). Parental Involvement in School Program at Bintang Juara Early Childhood Education (ECE). Journal of Primary Education, 8(5), 217-227.

Kadir, A., Shenoda, S., \& Goldhagen, J. (2019). Effects of armed conflict on child health and development: A systematic review. PLoS One, 14(1), e0210071. https://doi.org/10.1371/journal.pone.0210071.

Kidman, R., \& Thurman, T. R. (2014). Caregiver burden among adults caring for orphaned children in rural South Africa. Vulnerable Children and Youth Studies, 9(3), 234-246. https://doi.org/10.1080/17450128.2013.871379.

Kim, Y., Tanaka, K., \& Matsuoka, S. (2020). Environmental and economic effectiveness of the Kyoto Protocol. Plos One, 15(7), e0236299. https://doi.org/10.1371/journal.pone.0236299.

Lillard, A. S. (2016). Montessori: The science behind the genius. Oxford University Press.

Mahoney, G., \& Wiggers, B. (2007). The role of parents in early intervention: Implications for social work. Children \& Schools, 29(1), 7-15. https:// doi.org/10.1093/cs/29.1.7.

Malti, T., Gummerum, M., Keller, M., Chaparro, M. P., \& Buchmann, M. (2012). Early sympathy and social acceptance predict the development of sharing in children. PloS One, 7(12), e52017. https:/ / doi.org/10.1371/journal.pone.0052017.

Mathews, B., Yang, C., Lehman, E. B., Mincemoyer, C., Verdiglione, N., \& Levi, B. H. (2017). Educating early childhood care and education providers to improve knowledge and attitudes about reporting child maltreatment: A randomized controlled trial. PloS One, 12(5), e0177777. https://doi.org/10.1371/journal.pone.0177777.

Montessori, M. (1959). The absorbent mind. Lulu. com. 
Mufaziah, E., \& Fauziah, P. (2020). Kendala Orang Tua dalam Mendidik Anak Usia Dini pada Saat Pandemi Covid 19. Jurnal Obsesi: Jurnal Pendidikan Anak Usia Dini, 5(2), 1045-1051. https:// doi.org/10.31004/obsesi.v5i2.746.

Nirmala, B., \& Annuar, H. (2020). Home Visit: Strategi PAUD dari Rumah bagi Guru di Daerah 3T pada Masa Pandemi Covid-19. Jurnal Obsesi: Jurnal Pendidikan Anak Usia Dini, 5(2), 1052-1062. https://doi.org/10.31004/obsesi.v5i2.716.

Poulain, T., Vogel, M., Meigen, C., Spielau, U., Hiemisch, A., \& Kiess, W. (2020). Parent-child agreement in different domains of child behavior and health. PloS One, 15(4), e0231462. https:// doi.org/10.1371/journal.pone.0231462.

Seale, H., Heywood, A. E., Leask, J., Steel, M., Thomas, S., Durrheim, D. N., Bolsewicz, K., \& Kaur, R. (2020). COVID-19 is rapidly changing: Examining public perceptions and behaviors in response to this evolving pandemic. MedRxiv. https:// doi.org/10.1371/journal.pone.0235112.

Yulianingsih, W., Suhanadji, S., Nugroho, R., \& Mustakim, M. (2020). Keterlibatan Orangtua dalam Pendampingan Belajar Anak selama Masa Pandemi Covid-19. Jurnal Obsesi: Jurnal Pendidikan Anak Usia Dini, 5(2), 1138-1150. https:// doi.org/10.31004/obsesi.v5i2.740.

Yulianti, K., Denessen, E., \& Droop, W. (2019). Indonesian parents' involvement in their children's education: A study in elementary schools in urban and rural Java, Indonesia. 